Meta

Journal des traducteurs

Translators' Journal

\title{
The Poetic Translation of Translation: Reflections and Findings
}

\section{Tomás Ramos Orea}

Volume 37, numéro 3, septembre 1992

URI : https://id.erudit.org/iderudit/003765ar

DOI : https://doi.org/10.7202/003765ar

Aller au sommaire du numéro

Éditeur(s)

Les Presses de l'Université de Montréal

ISSN

0026-0452 (imprimé)

1492-1421 (numérique)

Découvrir la revue

Citer cet article

Orea, T. R. (1992). The Poetic Translation of Translation: Reflections and Findings. Meta, 37(3), 482-486. https://doi.org/10.7202/003765ar

\section{Résumé de l'article}

À partir de sa retraduction de Two Bodies d'Octavio Paz traduit vers l'anglais par Iain Forbes White, l'auteur propose des réflexions sur les problèmes que pose la retraduction de poèmes et souligne la nécessité de conserver ce qu'il appelle la " poéticité » du discours poétique. 


\title{
THE POETIC TRANSLATION OF TRANSLATION: REFLECTIONS AND FINDINGS
}

TOMÁS RAMOS OREA

Universidad de Granada, Granada, Spain

\begin{abstract}
Résumé
À partir de sa retraduction de Two Bodies d'Octavio Paz traduit vers l'anglais par lain Forbes White, l' auteur propose des réflexions sur les problèmes que pose la retraduction de poèmes et souligne la nécessité de conserver ce qu'il appelle la «poéticité» du discours poétique.
\end{abstract}

It was about 1960 that I became clearly aware of having been totally engulfed by the uneasy compulsion, both esthetic and literary, which is the result of the becoming involved in translating poetry poetically. Not that, prior to that date, I had tried my hand at such an endeavor. My attempts in the English Literature classes during the academic years 1955-1958 can well bear witness, as does the immature M.A. Thesis which, under the pretentious title Women in Modern English Poetry: With an Anthological Appendix, I submitted in March 1959 at the Central University of Madrid.

The reason for my said restlessness beginning 1960 and onward was due, on the one hand, to my becoming totally submerged in the translation of Dylan Thomas' Under Milk Wood which, although in prose, nevertheless contains a number of songs in poetical form 1 ; on the other hand, to the labyrinth meant by the preparation of such a thing as a Doctoral Thesis. Mine, which I read in May, 1961, also at the Central University of Madrid, was no exception. To mention its flaws with the hindsight of 29 years now elapsed, would not only be cruel but also useless.

At that time, I had begun to probe the possibilities (always intentionally poetic) of translating a discourse equally considered poetic. No wonder that my interest in the poetic translating of translation was present in this experimenting fever. And all, let us face it, just for the sake of pure dilettantism and humanistic cosmic vision. The specific cause of this paper lies on my coming across the following text $t^{2}$ :

\section{TWO BODIES}

(Freely adapted from a poem of Octavio Paz)

by Iain Forbes White

Two confronted bodies

Are sometimes waves

And night the sea.

Two confronted bodies

Are sometimes stones

And night the desert.

Two confronted bodies

Are sometimes knives

And night strikes a light.

Two confronted bodies

Are falling stars

In a vacant sky. 
Here is my rendering of the previous translation:

Dos enfrontados cuerpos
son a veces como ondas
y la noche el océano.
Dos enfrontados cuerpos
son cual piedras a veces
y la noche el desierto.
Dos enfrontados cuerpos
son a veces cuchillos
y la noche un destello.
Dos enfrontados cuerpos
son estrellas caídas
en un vacio cielo.

In 1960 I knew very little of Octavio Paz's work. Little, I mean, of his poetry. Nothing at all of his critical work in prose produced up to that time. Such work, whose coming of age, together with the creative dynamics of our poet - all of which referred to the area of my specific concern - would, among other productions, bear the fruit of his well known Traducción: Literatura y literalidad (Barcelona, Tusquets Editor, 1971). How far I was from imagining that I would be the one who on the 30th of April, 1982, would present Octavio Paz at the University of Alcalá de Henares, when he was awarded the Cervantes Prize. Is not all of this a marvellous plot of interactions and motives? Is not all of this, in the implementation of its unforseeable game, a situation comparable to some extent to the reverberations and connotations called for by literary translating?

The point is that, among those of my papers that had been gathering dust, it is now that I discover my rendering of Iain Forbes White's translation. And this the reason why I'm writing this. And this is also why I am urgently compelled to try to complete the circle...

First of all, I say to myself, let me find Octavio Paz's original poem. And after the appropriate search I find it:

\section{DOS CUERPOS}

Dos cuerpos frente a frente

son a veces dos olas

y la noche es océano.

Dos cuerpos frente a frente son a veces dos piedras y la noche desierto.

Dos cuerpos frente a frente son a veces raices en la noche enlazadas.

Dos cuerpos frente a frente son a veces navajas y la noche relámpago.

Dos cuerpos frente a frente son dos astros que caen en un cielo vacío. 
Asueto [1939-1944], en Octavio Paz, Libertad bajo palabra. Obra poética (1935-1957). Letras mexicanas, México: Fondo de Cultura Económica, 1974 [1960], pp. 43-44.

The English translator has done without the stanza in the middle. Greedily, in the presence of "my treasure," with the two texts coupled and placed face to face as well, I allow myself to be soaked in the tide of reflections rushing towards me. The first thing I perceive - and I hope to refer to it more in detail later on - is that the English rendering has performed its instrumental role; it has (in a way that always shirks the absolute understanding) put to a test the nature of the text translated.

Another perception of no less relevance is also the one concerning the translator as an interpreter, operating between the world set by the original poem, on the one hand, and the presumed reality affecting the reader to whom the translation is addressed, on the other. Such an interpretative instance becomes verifiable and, at any rate, assumed by itself within the poetic cosmic vision of the translator and may, no doubt, lead him to bulky errors of perspective which mainly consist, we believe, in his wish to modify clumsily the stylistic "key" the author may have desired to apply in his poem. To produce a rendering which brims over with carefully chiselled terms, when the intention of the author conveys some conscious roughness of strain or the use of certain harsh lexemes under a contrastive eagerness, is, for example, as wrong and inappropriate as just the contrary: to defile the original expression of the poem by means of a "cheap" version void of sensitivity...

I'm trying to say that the personal interpretation that I took for granted of the interdependence between the English version of Forbes White and Octavio Paz's original (unknown to me at the time) was a wishfully, positively, poetic interpretation. Whether more or less "poetic" than that of Octavio Paz's himself, is an issue which rather than for Octavio Paz, would of course, be for the critical reader to decide by means of his assenting to it or not. Now then if I have, at all times, had one thing clear, it is that my translation seeks a result in respect of something which has been realized, which has been carried out with an inner poetic will.

Through the medidation of the two contrastive texts (Octavio Paz's original and that of my translating the translation) I can't help noticing that what really comes through the filter of the rendering is, more than anything else, if not exclusively, that "poetic will," that "stylistic effort" to which I'm continually referring. Such a meditation becomes two-folded on the basis of these two obvious issues: First: the term translation, whenever applied to poetry, takes on a tremendous load of impropriety. Secondly and as an appendicular sequel of the previous statement: when referring to certain poetical texts, in their quality of source language or a quo language, their transit to texts of result, target or ad quem language is accomplished under the form of some sort of reinvention or of recreation.

Either the inventive or the creative load of such performance is produced in proportional equivalence to the poetic will of the author, as far as the nature of the language goes. And contrariwise, when the nature of the source language is less poetical, there will be a greater - and ever increasing - probability that the final rendering would contain analytical, discursive, "faithful" components. In other words: components prosaicly translatable.

The issue just accounted for links us inevitably with the theme of the poetic rendering of poetry as a means to probe into the nature of the text to be rendered. ${ }^{3}$ Stated in more vivid terms: the supposed faithfulness of a given source language is not likely to be maintained after two or three sifting processes corresponding to a similar number of 
translations. It so happens that the so-called faithfulness, based on conceptual contents related to the visible and the tangible, experiences the same wearing away as the currency which undergoes several consecutive exchanges: both of them end up by being reduced to the least of their substance. It seems as if the concretion and "bodiness" of the concepts just referred to, on piercing the diaphragm or screen of translation, were losing tangible pieces of their own integrity, of their own bulk, of their own volume... to the point of disappearing, melted away in an unintelligible flow. This is what $I$ am talking about when someone speaks of rendering the supposed plot or content of a poem. It turns out that "faithfulness" is nothing but an extremely subjective notion, and it so happens that this subjectivity, when dealing with the measurable and concrete, with the supposedly objective... paradoxically generates its destruction, its termination by attrition.

Surprisingly enough, the discourses liable to be recreated or reinvented through poetic rendering, rather than taking the presumed and unmovable semantic stability of the text (issue which we only suggest as an instrument of theoretical reference, while being well aware of its unlikeness), take as their starting point or source language an interpretative potentiality, faithful to the generating reality of the source language insofar as the part it plays as indispensable starting motor for any other future reality, but at the same time turning each of the reinventive or recreative possibilities of the said a quo text into a construction resistant to the abrasive filter embodied in the sifting of all translation. And the reason for this resistance, for this high-quality endurance, is no other than the own pliable nature, always sensitive to essential mimesis, of the reinventing or recreating version. To some extent, something like the lesson which underlies the fable of the stout acorn tree and the slender reed: the former is ripped out by its roots by the whirlwind, while the latter, because of its suppleness withstands the battering of the wind.

In the poem taken as an example for this essay the English rendering serves as a guide or as an orientating beacon. Let us try to point out the principles which guarantee our choice of implemented potentialities, while fully sparing the "shaping shape" of the original. The first thing I find convenient to take into account is the fact that some of the requirements of rhyme and rhythm, however minimal, seemed to me to be desirable, as organizing steps in my poetic endeavor. Even in 1960, it sufficed me to observe the English translation in order to realize that whatever Octavio Paz's original might be, such an original would permit, or rather, would prompt, a recreated version, which has turned out to be absolutely true. The expressive porosity of the lexia "frente a frente" allows its conceptualization to be rendered with no damage whatsoever by means of the successive lexeme confronted, enfrontados...

What follows is easier and even more logically to be foreseen: of the "dos cuerpos frente a frente" in Octavio Paz's poem, a chain of poetical similes is being predicated, all of them made up of lexemes, the intention and nature of which are stylistically recreatable and, above all, retranslatable. Dos cuerpos frente a frente are "olas", "waves" and "ondas"; are "piedras", "stones" and "piedras" again; are "navajas", "knives" and "cuchillos"; are "astros", "stars" and "estrellas". Let it be observed once again how through the implementation of the translating act we probe into the nature of the text to be translated; how by means of our movement towards the final text which every target language implies (or decodifying result) we gather information on the source language from which we set out.

It must be observed how, as far as faithfulness is concerned both of the English version and my retranslation as well, no detriment seems to have been produced in respect of Octavio Paz's original. Rather, I would go as far as to say that the evident impossibility for a complete synonymy to exist between lexemes in any given language, turns itself into a splendid virtuality which gives to the practice of the free adaptation its proven 
character, this being the reason why its language does not crack or fracture. Once more, the fable of the reed and the acorn tree.

Curiously, the presumably faithful translation of some poems, when rerendered several times, ends up by becoming unintelligible due to the erosion of the conceptualization contained within their lexemes. And to the contrary, the repeated retranslation of the same poem does not, in my opinion, impair their poetic halo, the diamond hidden within themselves. Such a diamond-like quality, rather than to be understood as a physical piece of hard matter, consists of its capacity to give out reflections, which are always different, and yet always faithful to their origin: that is to say, faithful to the stone by which and from which they are actually generated. This, and no other, is the simile we are proposing for the original text of the poem (source language) and the potential recreations or different renderings in their terminal result (target language) if attempted with a poetic will.

By means of recreating or of reinventing, the metaphorical kernel of the poetically renderable poem acts as a guiding lamp, and of which there may exist an indefinite number of versions, all of them appropriate and equidistant, provided that they were attempted with the poetic perspective and will to which we have continually referred. The poetic recreation of a previous, and equally poetic, recreation is, additionnally, a good proof that what comes through the filter, in between the intervening nets of the dichotomy concept/expression, always unmarred and always valid, is the potentiality which underlies every poem - especially if it is truly a poem - to generate in its turn another poem.

\section{NOTES}

1. I keep a call-card from Julián Marías in which, while acknowledging receipt of my gift of Under Milk Wood's translation, he refers to it as "poem."

2. In Wales, edited by Keidrych Rhys, no. $42 / 44$ (September, 1959), p. 51.

3. See, Tómas Ramos Orea (review of) John Donne: Poesía erótica. Introducción, versión castellana y notas de Luis Carlos Benito Cardenal (Barcelona, Barral, 1978), in EFI, 4-5, pp. 183-186; id., (review of) Poesía inglesa: Antología bilingüe. Traducción por José Siles Artés (Barcelona, 1979), in EFI, 10, pp. 193-201. 